\title{
Presence of cellulolytic and xylanolytic activities in the gut fluid of grasshopper Oxya velox
}

\author{
Suman Dash, Lucky Hazera Mubareka, Rajib Kumar ShIL, \\ SUMAN MOJUMdER, DWAIPAYAN SIKDAR * \\ Department of Biochemistry and Molecular Biology, University of Chittagong, Chittagong, Bangladesh
}

\begin{abstract}
Insect guts, particularly of phytophagous insects, are considered as intriguing bioprospecting sources of cellulase and xylanase due to their use in biofuel industry. In this study, the activities of cellulase and xylanase were identified in the gut fluid of grasshopper, Oxya velox, and characterized. Qualitative assays of gut fluid carried out

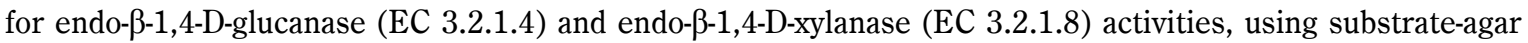
plate method, revealed clear transparent zones against the red-stained background. When measured by dinitrosalicylic acid method, the gut fluid had $0.759 \pm 0.005 \mathrm{U}$ and $0.303 \pm 0.002 \mathrm{U}$ of endoglucanase and endoxylanase activities, respectively, per mg of protein. In the gel zymogram, four distinct cellulolytic protein bands and one xylanolytic protein band were detected against substrates carboxymethyl cellulose and xylan, respectively. The optimal temperature and $\mathrm{pH}$ of both endo- $\beta-1,4-\mathrm{D}$-glucanase and endo- $\beta-1,4-\mathrm{D}$-xylanase were $55^{\circ} \mathrm{C}$ and 5 , respectively. Preincubation at $70^{\circ} \mathrm{C}$ for 20 min resulted in almost complete loss of endo- $\beta$-1,4-D-glucanase activity as shown by zymography. The presence of both cellulase and xylanase activities suggested that $O$. velox could be considered as a model for studying the process of lignocellulose digestion in insect gut; the insect could also serve as a good source of enzymes for biofuel production.
\end{abstract}

Key words: Oxya velox, cellulase, xylanase, gut fluid, biofuel

\section{Introduction}

To meet the increased energy demand resulting from the global economic development and population growth, utilization of renewable energy is gaining interest. Renewable energy may help prevent climate change and slow down global warming, and its source is inexhaustible. According to International Energy Outlook (IEO) report 2016 , renewable energy is the world's fastest growing source of energy, with an average growth rate of $2.6 \%$ per year. As an alternative to the depleting fossil fuel, biofuel produced using lignocellulosic plant biomass, which is abundant and low-cost source of energy in the biosphere (Cairo et al., 2011), is currently gaining tremendous attention from the scientists as one of the prominent forms of renewable energy (Schubert, 2006).

Lignocellulose is a major component of the plant biomass. The lignocellulosic biomass consists of hemicellulose, cellulose, and lignin constituting $20-40 \%, 40-60 \%$ and $10-25 \%$, respectively (Yang et al., 2007). Cellulose is a $\beta$-1,4-linked polymer of glucose units (Chen, 2014) and consists of interstrand hydrogen bonds forming a highly stable crystalline lattice (Dodd and Cann, 2009). Hemicellulose consists primarily of xylan and is the second most abundant polymer in the plant material after cellulose. Xylan consists of a main chain of $\beta$-1,4-linked xylopyranose residues that is most often replaced by $\alpha$-linked units of arabinofuranose and methylglucuronic acid (Brennan et al., 2007). Lignin, a three-dimensional polymer of phenylpropanoid units, can be considered as the cellular glue that provide the plant tissue and the individual fibres with compressive strength and the cell wall with stiffness, in addition to providing resistance against insects and pathogens (Rubin, 2008).

Enzymatic hydrolysis of the lignocellulosic materials is of great interest for its application in various industries because the process is environment-friendly and highly

\footnotetext{
* Corresponding author: Department of Biochemistry and Molecular Biology, University of Chittagong, Chittagong, Bangladesh; e-mail: dsikdar@cu.ac.bd
} 
efficient and involves lower energy requirements than physical or chemical hydrolysis (Sheng et al., 2015). During hydrolysis, cellulose is degraded to fermentable glucose by the synergistic action of three glycosidic hydrolases: endo- $\beta-1,4$-glucanases (EC 3.2.1.4), exo- $\beta-1,4$-cellobiohydrolases (EC 3.2.1.91), and $\beta$-glucosidases (EC 3.2.1.21) (Clarke, 1997). Xylanases have been found to be important in the total hydrolysis of hemicelluloses containing lignocellulosic materials. In the process of bioethanol production from lignocellulosic materials, xylanases can improve the hydrolysis of cellulose into fermentable sugars by removing xylan that restricts the access of cellulases to cellulose surfaces. Thus, hydrolysis of pretreated lignocellulosic raw materials, even those with a low residual content of xylan, by xylanases has been shown to significantly improve the hydrolysis of cellulose (Zhang et al., 2011). Moreover, xylose can also be fermented to ethanol or xylitol, which is of higher value than ethanol (Mattam et al., 2016).

In spite of a large number of studies dedicated to developing a cost-effective process for bioethanol production, an efficient process for the conversion of lignocellulosic biomass to fermentable sugars is yet to be established. This is, at least, partly due to the recalcitrance of the cellulosic biomass which restricts the access of enzymes. Therefore, it is proposed that discovering of new enzymes with desirable features or improving the existing ones through biotechnological means can reduce the cost of biofuel production (Lynd et al., 2008; Yang et al., 2011).

Insects can process lignocellulosic biomass much more efficiently with their highly specialized gut systems and can be considered as highly efficient natural bioreactors (Sun and Scharf, 2010). Thus, insect gut could be a prospecting source of novel cellulases and xylanases which could be used in biofuel and other industries to reduce costs. Both cellulase and xylanase have many applications in various industries including food, feed, paper and pulp, textile, and laundry (Juturu and $\mathrm{Wu}$, 2012; Kuhad et al., 2011). Although reports on screening of insects for cellulolytic activities and characterization of cellulases isolated from various insects are available (Oppert et al., 2010; Su et al., 2013; Wills et al., 2010a), less attention has been paid to the insect xylanase in previous studies (Arakawa et al., 2009; Mohamed et al., 2018; Padilla-Hurtado et al., 2012). Moreover, there are few reports on the presence of both cel- lulolytic and xylanolytic activities in any specific insect species (Shi et al., 2011), which are essential for efficient digestion of the lignocellulosic plant materials. Grasshoppers (Orthoptera: Acrididae) are serious pests affecting both agriculture and pasture in many countries of the world (Eziashi and Chidi, 2017). In this study, the activities of cellulase and xylanase of grasshoppers, Oxya velox, one of the major pests of rice (Kumar etal., 2014), were investigated with an aim of using these enzymes in biofuel and other industries, as well as to understand the process of lignocellulose digestion in phytophagous insect through future study.

\section{Materials and methods}

\section{Chemicals}

Carboxymethyl cellulose (CMC), beechwood xylan, congo red, bovine serum albumin (BSA), bisacrylamide and tetramethylethylenediamine (TEMED) were purchased from Sigma-Aldrich Chemicals (St. Louis, MO, USA). 3,5-Dinitrosalicylic acid (DNSA) was bought from Loba Chemie (India). Ammonium persulfate (APS) was obtained from Bio Basic Canada Inc. Acrylamide and sodium dodecyl sulfate (SDS) were procured from Promega (USA). All other chemicals used were purchased from BDH (England) and Merck (Germany).

\section{Insect collection}

Fifty adult $O$. velox insects were collected from the Chittagong University campus, Bangladesh, in June 2015. During collection, the insects were in active feeding state and were kept on their host plants until dissection.

\section{Gut dissection and fluid collection}

All the collected insects were dissected on the day of collection. After immobilizing on ice for around half an hour, the insects were kept abdomen side up on Petri dishes placed on ice and dissected to remove the intact guts. The dissected guts were transferred to $1.5 \mathrm{ml}$ microcentrifuge tubes. Then, the guts were cut into small pieces, homogenized through vortexing to ensure fluid extraction and centrifuged at $10,000 \mathrm{rpm}$ for $10 \mathrm{~min}$ at $4^{\circ} \mathrm{C}$. Supernatants were transferred to new micro centrifuge tubes $(1.5 \mathrm{ml})$ and stored at $-40^{\circ} \mathrm{C}$.

\section{Detection of cellulolytic and xylanolytic activities}

A modified substrate-agar plate assay (Teather and Wood, 1982) was used to detect endo- $\beta-1,4$-glucanase 
and endo- $\beta-1,4$-xylanase activities. The procedure used for endo- $\beta-1,4$-glucanase was as follows: $1 \% \mathrm{CMC}$ and $3 \%$ agar were mixed with $0.1 \mathrm{M}$ Na-acetate buffer ( $\mathrm{pH}$ 5.3) and poured on Petri dishes, and the gel was allowed to solidify. A $110 \mu$ g of gut protein, diluted with water, was loaded into the holes punched in the center of the plates. After incubation at $37^{\circ} \mathrm{C}$ for overnight, the plates were stained with $0.1 \%$ Congo red for 10-15 min before destaining with $0.5 \mathrm{M} \mathrm{NaCl}$ solution for 15-20 min for several times. Appearance of clear zones around the sample holes against the red-stained background of the agar plates confirmed the activity of endo- $\beta$ - 1,4 -glucanase. The same procedure was followed for detecting the endo- $\beta-1,4$-xylanase activity, with an exception that beechwood xylan was used in place of $1 \% \mathrm{CMC}$.

\section{Measurement of the endo- $\beta-1,4$-glucanase and endo- $\beta-1,4$-xylanase activities}

The activities of endo- $\beta-1,4$-glucanase and endo- $\beta-1,4$ xylanase were quantified as the rate of production of reducing sugars from their substrates using a modified DNSA assay (Miller, 1959). For quantifying the glucanase activity, $15 \mu \mathrm{l}$ of gut fluid containing $50 \mu \mathrm{g}$ of total proteins was mixed in microcentrifuge tubes with $235 \mu \mathrm{l}$ of $1 \% \mathrm{CMC}$ suspended in $0.1 \mathrm{M}$ Na-acetate buffer ( $\mathrm{pH}$ 5.3), and incubated for $30 \mathrm{~min}$ at $37^{\circ} \mathrm{C}$. The reactions were stopped by adding $450 \mu$ of DNSA solution followed by heating the microcentrifuge tubes in boiling water for $10 \mathrm{~min}$. After adding 40\% Rochelle salt, the reaction mixtures were cooled at room temperature for $5 \mathrm{~min}$ and centrifuged at $10,000 \mathrm{rpm}$ for $5 \mathrm{~min}$. After centrifugation, the supernatants were transferred to new microcentrifuge tubes to measure absorbance at $540 \mathrm{~nm}$ on an UV-visible spectrophotometer (Shimadzu).

For preparing blank, DNSA was mixed with the substrate before the addition of the gut fluid so that the enzymes present in the fluid could not hydrolyze CMC. One unit of cellulolytic activity was defined as the amount of enzyme required to produce $1 \mu \mathrm{mol}$ of reducing sugar per minute at $37^{\circ} \mathrm{C}$ and $\mathrm{pH}$ 5.3. A standard curve of absorbance against amount of glucose (50$300 \mu \mathrm{g}$ ) was constructed to calculate the amount of reducing sugars released during endo- $\beta$-1,4-glucanase assay.

The same procedure was followed for measuring the endo- $\beta$-1,4-xylanase activity, with the exception that xylan was used as substrate instead of CMC and the standard curve was constructed using xylose instead of glucose.

\section{Effect of temperature and $\mathrm{pH}$ on enzyme activity}

To detect optimal temperature and $\mathrm{pH}$ of the enzymes, their activities were measured in gut fluid at different temperatures and $\mathrm{pH}$ values, respectively. The effect of temperature on the enzyme activity was examined by incubating the reaction mixture (containing $1 \%$ $\mathrm{CMC}$ or $1 \%$ Xylan as substrates for endo- $\beta-1,4$-glucanase or endo- $\beta-1,4$-xylanase activity, respectively, in $0.1 \mathrm{M} \mathrm{Na}$ acetate buffer, $\mathrm{pH}$ 5.3) over a range of temperatures from 35 to $85^{\circ} \mathrm{C}$. The temperatures at which the highest activities of enzymes were detected were considered as optimum and calculated as $100 \%$.

The optimal $\mathrm{pH}$ for the enzyme activity was determined by measuring the hydrolysis of substrates in a series of buffers at various $\mathrm{pH}$ values ranging from 4 to 10 . The following were used for evaluation: Na-acetate buffer $(0.1 \mathrm{M})$ for $\mathrm{pH} 4$ and 5 , phosphate buffer $(0.1 \mathrm{M})$ for $\mathrm{pH}$ 6 and 7, Tris- $\mathrm{HCl}$ buffer $(0.1 \mathrm{M})$ for $\mathrm{pH} 8$, and glycine$\mathrm{NaOH}$ buffer $(0.1 \mathrm{M})$ for $\mathrm{pH} 9$ and 10 . The $\mathrm{pH}$ values at which the enzymes showed the maximum activities were considered as optimum and calculated as $100 \%$.

\section{Zymography}

Sodium dodecyl sulfate-10\% polyacrylamide gel electrophoresis (SDS-PAGE) (Laemmli, 1970) was performed, with some alterations, to detect the activities of endo- $\beta$-1,4-glucanase and endo- $\beta-1,4$-xylanase through zymography (Schwarz et al., 1987). Briefly, SDS-10\% PAGE resolving gel was prepared by adding $1 \%$ substrate (CMC for endo- $\beta$-1,4-glucanase and xylan for endo$\beta$-1,4-xylanase) with $10 \%$ APS and TEMED and incubated for $1 \mathrm{~h}$ at room temperature. Gut fluid samples $(20 \mu \mathrm{g})$ of $O$. velox were solubilized in 1 volume of sample buffer (50 mM Tris-HCl, pH 6.8, 2\% SDS, 10\% glycerol, $1 \% \beta$ mercaptoethanol, and $0.01 \%$ bromophenol blue) and loaded onto the gel. Proteins in the samples were separated at a constant voltage of $90 \mathrm{~V}$ at $4{ }^{\circ} \mathrm{C}$ for approximately $6 \mathrm{~h}$ or until the bromophenol blue dye reached the bottom of the resolving gel.

After electrophoresis, the gel was washed five times (each for $30 \mathrm{~min}$ ) with $150 \mathrm{ml}$ of wash buffer $(0.1 \mathrm{M} \mathrm{Na}-$ succinate, $\mathrm{pH} 5.8$ and $0.1 \% \beta$-mercaptoethanol) at room temperature, except the last wash which was performed at $30^{\circ} \mathrm{C}$. Then, the gel was stained with $0.1 \%$ Congo red 
for $30 \mathrm{~min}$ and destained by washing in $1 \mathrm{M} \mathrm{NaCl}$ solution at room temperature to identify the zones of clearing, where substrate was degraded by the enzyme. Followed by destaining, $100 \mu \mathrm{l}$ of glacial acetic acid was added to the gel wash buffer for better visualization of clearing areas (Waeonukul et al., 2007). To determine the thermal stability of endo- $\beta-1,4$-glucanase, the gut fluid of $O$. velox was preincubated at $70^{\circ} \mathrm{C}$ for $20 \mathrm{~min}$ before loading onto gel.

\section{Measurement of the protein concentration in the gut fluid of $O$. velox}

Protein concentration in gut fluid was measured by using Folin-Ciocalteu reagent (FCR) method (Lowry et al., 1951). Different aliquots of standard BSA solution $(250 \mu \mathrm{g} / \mathrm{ml})$ were pipetted out into different tubes, and the aliquots of samples were taken in separate tubes. Equal amount of alkaline copper sulfate was added in each tube and then allowed to stand for $15 \mathrm{~min}$. The same amount of FCR was added to each tube and the tubes were incubated for $30 \mathrm{~min}$. Absorbance was measured at $650 \mathrm{~nm}$ against a proper blank in which no protein solution was added. The protein concentration in the gut fluid was calculated from the standard curve.

\section{Statistical analysis}

The results are presented as mean \pm standard deviation $(n=3)$.

\section{Results and discussion}

Phytophagous insects are now considered to be a novel and efficient sources of enzymes that can be used for the degradation of lignocellulosic biomass, which can reduce cost of biofuel production. These enzymes may be useful for other industrial applications as well. Moreover, study of the digestive enzymes of the pests could be helpful to control them through searching and/or designing proper inhibitor(s). Here, we report for the first time the presence and characteristics of cellulase and xylanase and evaluate the cellulolytic and xylanolytic activities in the gut fluid of orthopterian insect $O$. velox (grasshopper).

\section{Qualitative and quantitative assay of cellulase and xylanase activities}

To determine the presence of cellulase and xylanase activities in the gut fluid of $O$. velox, plate assay were performed. Figure 1 shows the clear zones around the

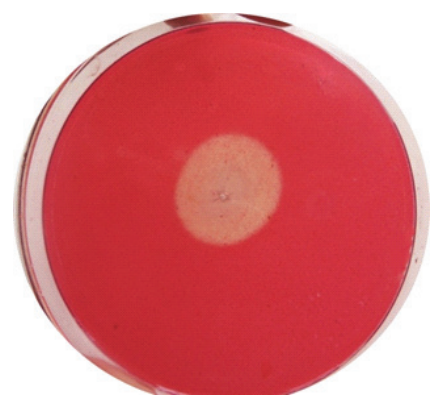

A

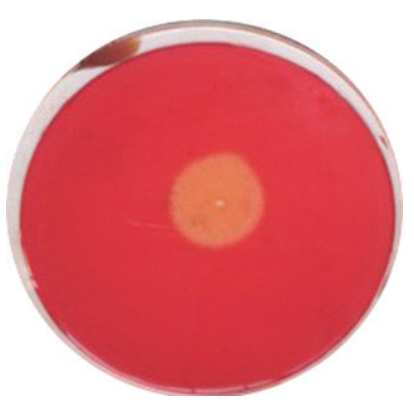

B
Fig. 1. Presence of A) cellulolytic activity in CMC-agar plate and B) xylanolytic activity in xylan-agar plate. Gut fluids were added to the central holes of agar plates containing CMC or xylan prepared in Na-acetate buffer ( $\mathrm{pH}$ 5.3), and the plates were incubated overnight at $37^{\circ} \mathrm{C}$. Plates were stained with Congo red followed by destaining with $0.5 \mathrm{M} \mathrm{NaCl}$

holes where the gut fluids were added, proving the presence of both enzymes. Previously, endo- $\beta-1,4$-glucanase activity has been detected in the digestive fluids of insects belonging to 10 different taxonomic orders including Blattodea, Coleoptera, Diptera, Isoptera, Lepidoptera, Orthoptera, Plecoptera, Phasmatodea, Trichoptera, and Thysanura (Wills et al., 2010b). Oppert et al. (2010) reported the presence of cellulolytic activity in fluids of the guts and heads of 63 phytophagous or xylophagous insect species belonging to eight different orders including Diptera, Orthoptera, Colleoptera, Hymenoptera, Lepidoptera, Dictyoptera, Dermaptera, and Isoptera. They used two different substrates CMC and microcrystalline cellulose, for evaluating the endo- $\beta-1,4$ D-glucanase activity and complete cellulolytic activity, respectively. The digestion of cellulose by insects was traditionally attributed to the symbiotic microbes in their guts, but lately it has been found that endogenous insect cellulases also play a crucial role in the digestion process. Endogenous cellulases have been found in insects belonging to various orders including Blattaria, Coleoptera,Hemiptera, Phthiraptera Orthoptera, and Hymenoptera (Fischer et al., 2013; Watanabe and Takuda, 2010; Wills et al., 2011). Previously, we identified cellulolytic bacteria in the guts of $O$. velox (Shil et al., 2014). All herbivorous insects exhibiting endogenous cellulase activity contain at least one cellulase gene encoding class 9 glycosal hydrolases (GH9), although coleopteran insects possess endogenous cellulases of other $\mathrm{GH}$ families including GH5, GH45, and GH48, which are likely acquired from microbes via successive events of horizontal 
gene transfer (Fischer et al., 2013; Shelomi et al., 2016). Cloning and sequencing the cellulase genes of $O$.velox would help ascertain which gene family these cellulases belong to.

Xylanases are enzymes necessary for degradation of xylan constituting hemicellulose, the noncellulosic part of lignocellulosic biomass, to xylose. Thus, these enzymes play dual role in second-generation biorefineries: 1) they facilitate the access of endoglucanase for deconstruction of cellulose through degradation of xylan; after which 2) then xylose the degraded product of xylan, can be fermented to ethanol. Xylanases also have numerous biotechnological and industrial applications (Uday et al., 2017). Generally, industrial processing conditions are harsh involving extreme $\mathrm{pH}$, temperature, inhibitors, etc. Hence, sufficiently stable enzymes that are able to withstand such conditions are recommended to be used in industries. However, most of the reported xylanases do not meet this criterion (Khandeparker et al., 2017). Moreover, high costs of production hinder the use xylanases in bioethanol and other industries (Ali et al., 2017). Therefore, finding a novel source of xylanases is crucial. Although bacteria, fungi, terrestrial plant tissues, and digestive juices of animals are extensive sources of xylanases (Xu et al., 2016), the digestive extracts of many insects, for example, wood-feeding termites (Ali et al., 2017; Arakawa et al., 2009), red palm weevils (Mohamed et al., 2018), coffee berry borers (Padilla-Hurtado et al., 2012), larvae of scarab beetles (Holotrichia parallela) (Sheng et al., 2015), also contain xylanases. Here, we report for the first time the presence of xylanase activity in the gut extract of $O$. velox. To date, it has been believed that xylanases present in insects are secreted mainly by the symbiotic gut microorganisms such as bacteria, fungi and protozoa (insect digestive glycosidases). Most of these xylanases are classified under the $\mathrm{GH}$ families 10 and 11 on the basis of the similarities in their amino acid sequences, catalytic domains, protein folds and overall architecture (Wakiyama et al., 2008).

The activities of cellulase and xylanase were also measured quantitatively by DNSA method. The activities of endo- $\beta$-1,4-D-glucanase and endo- $\beta$-1,4-D-xylanase were calculated to be $0.759 \pm 0.005 \mathrm{U} / \mathrm{mg}$ and $0.303 \pm 0.002 \mathrm{U} / \mathrm{mg}$ of protein, respectively. Willis et al. (2011) reported a cellulase activity of $0.016 \mathrm{U} / \mathrm{mg}$ of protein $\left(\right.$ at $50^{\circ} \mathrm{C}$ and $\mathrm{pH} 6$ ) in the gut fluid of the larvae of the coleopteran insect, Tribolium castaneum. Similarly, the activities of endoglucanase and xylanase in the gut content of the larvae of Asian longhorned beetle (Anoplophora glabripennis) were measured to be $0.41 \mathrm{U} / \mathrm{mg}$ and $0.058 \mathrm{U} / \mathrm{mg}$ of protein, respectively (Geib et al., 2010). A cellulolytic activity higher than $0.5 \mathrm{U} / \mathrm{mg}$ of protein against $\mathrm{CMC}$ substrate were found in the gut fluids of insect species belonging to the orders of Coleoptera, Isoptera, and Orthoptera (Oppert et al., 2010). The gut fluid of $O$. velox showed relatively high activities of endoglucanase and xylanase, compared to the gut fluids of many other insect species. However, it is difficult to compare the enzyme activities among different insect species as the activity of an enzyme depends on many factors, including assay conditions, feeding status of insects, concentration of the desired proteins in the gut fluid, and so on. Thus, it cannot be concluded that the higher activities of endoglucanase and xylanase reported in the present study are due to the catalytic strength of the enzymes of $O$. velox without purifying the enzymes. It has been reported that the grass-consuming grasshoppers and wood-consuming wood borer have higher activities of cellulase and xylanase in their gut content compared to the leaf-consuming silkworms (Shi et al., 2011).

\section{Detection of enzyme activity by zymography}

To detect the proteins associated with the activities of endoglucanase and endoxylanase, zymography of the $O$. velox gut fluid was performed. The zymogram showed four protein bands representing endoglucanase activity (Fig. 2A) and one protein band corresponding to endoxylanase activity (Fig. 2B). Four protein bands for endoglucanase activity were also found in the gut fluid of Dissosteria carolina grasshopper (Wills et al., 2010a) and coleopteran Podentia quatuordecimpunctata insect (Uddin et al., 2012). Several explanations have been put forth for multiple forms of insect cellulases: 1) proteolytic cleavage of enzymatic proteins by proteases present in the insect gut that are produced either by the insects or by the symbiotic microbes; 2) differential glycosylation of an enzyme; 3 ) duplication of genes encoding cellulases; and 4) cellulases produced by the symbiotic microorganisms (Sami and Shakoori, 2006). Beetle Phaedon cochleariae has at least three cellulase genes which probably encode divergent enzymes (Girard and Jouanin, 1999), whereas four cellulase genes have been reported in termite genome (Terrapon et al., 2014). Dif- 


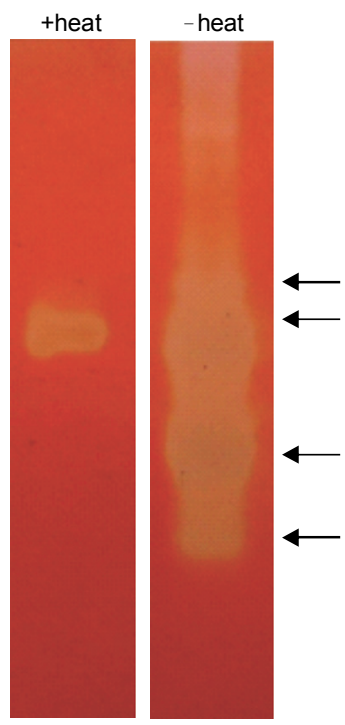

A

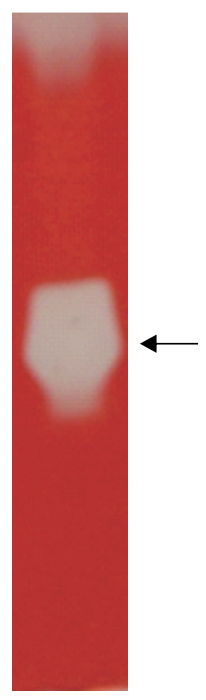

B

Fig. 2. Zymography for the activity of A) endo- $\beta 1,4$-glucanase and B) endo- $\beta 1,4$-xylanase activity of $O$. velox gut fluid. Gut fluid was separated using SDS-10\% PAGE, and gels were stained for CMC (for endoglucanase) or xylan (for xylanase) using $0.1 \%$ Congo red. After destaining with $1 \mathrm{M} \mathrm{NaCl}$, clear areas were found as bands where CMC or xylan was degraded. In figure (A) the lane marked as "-heat" indicates that the gut fluid were used without any heating, whereas lane marked as "+heat" indicates that gut fluid was heated at $70^{\circ} \mathrm{C}$ for $20 \mathrm{~min}$ before loading to the gel

ferent levels of glycosylation were suggested as a reason for appearance of more than one form of bands indicating cellulase activity, as glycosylation was required for the activity of cellulases of beetle Apriona germari (Wei et al., 2005). Further experiments are necessary to confirm the origin of different cellulase proteins found in the $O$. velox. A single protein of $34 \mathrm{kDa}$ representing endoxylanase activity was also found in the gut fluid of the larvae of Asian longhorned beetles, Anoplophora glabripennis (Geib et al., 2010).

\section{Effect of temperature and $\mathrm{pH}$ on enzyme activity}

The effect of temperature on the activities of endo- $\beta$ 1,4-glucanase and endo- $\beta-1,4$-xylanase has been presented in Figure 3. The optimal temperature of both endoglucanase and endoxylanase was $55^{\circ} \mathrm{C}$ at which their activities were $1.113 \pm 0.006 \mathrm{U} / \mathrm{mg}$ and $0.705 \pm 0.003 \mathrm{U} / \mathrm{mg}$ of protein, respectively. The endoglucanase activity was $63 \%$ at $35^{\circ} \mathrm{C}$ and $36 \%$ at $65^{\circ} \mathrm{C}$ whereas the endoxylanase activity reached $38 \%$ at $35^{\circ} \mathrm{C}$ and $49 \%$ at $65^{\circ} \mathrm{C}$, indicating that xylanases of this insect are more thermostable

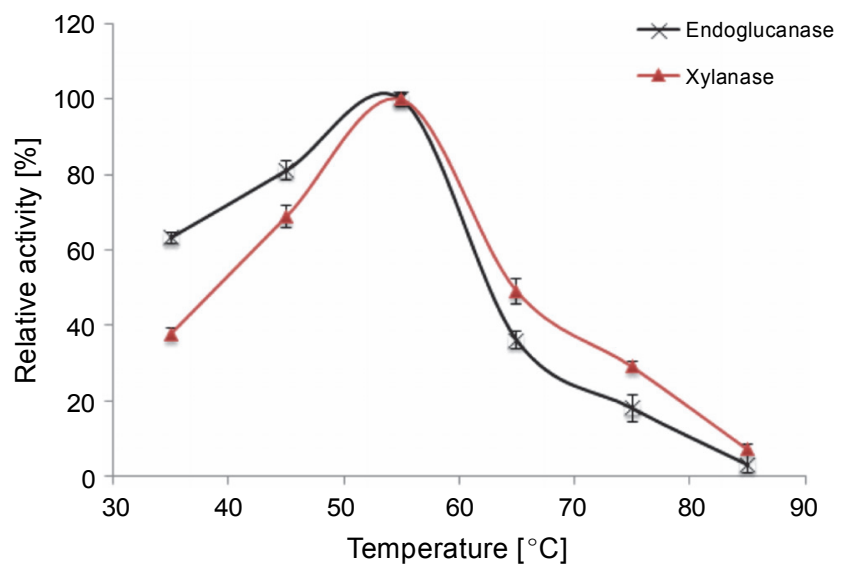

Fig. 3. Effect of temperature on the activities of endo- $\beta-1,4-D-$ glucanase and endo- $\beta-1,4-\mathrm{D}$-xylanase. Gut fluid of $O$. velox was mixed with $1 \% \mathrm{CMC}$ (for cellulase) or $1 \%$ xylan (for xylanase) in $0.1 \mathrm{M} \mathrm{Na}$-acetate buffer ( $\mathrm{pH}$ 5.3), and incubated at different temperatures from $35^{\circ} \mathrm{C}$ to $85^{\circ} \mathrm{C}$, and then assayed for enzyme activities by DNSA method. The highest activity was considered as $100 \%$. Each point is the average of three determinations, and error bars represent the standard deviation

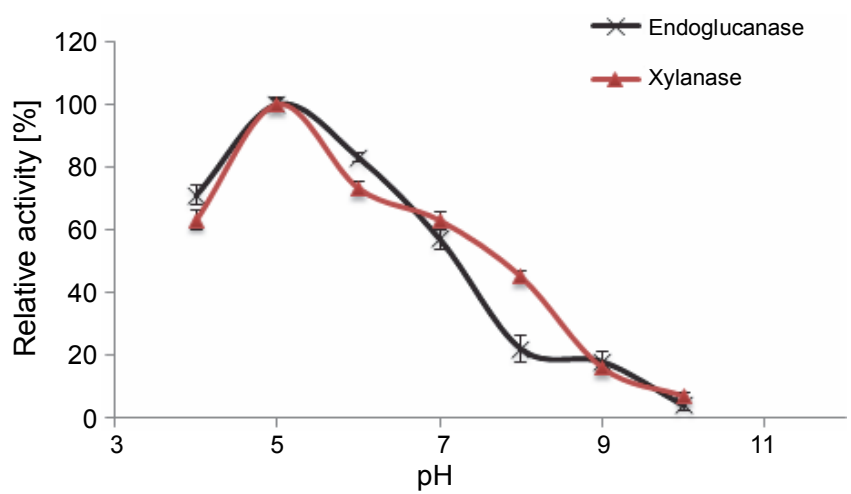

Fig. 4. Effect of $\mathrm{pH}$ on the activities of endo- $\beta$-1,4-D-glucanase and endo- $\beta-1,4-D$-xylanase. Gut fluid was incubated with $1 \%$ substrate solution prepared in the $0.1 \mathrm{M}$ buffers of different $\mathrm{pH}$ values at $37^{\circ} \mathrm{C}$ and assayed for enzyme activity. The highest activity was considered as $100 \%$. Each point is the average of three determinations, and error bars represent the standard deviation

than cellulases. The zymogram of gut fluid preincubated at $70^{\circ} \mathrm{C}$ for $20 \mathrm{~min}$ also showed loss of endoglucanase activity, indicated by the disappearance of three cellulase bands (Fig. 2A). The optimal temperature for endoglucanase activity has been reported to be in the range of $50-55^{\circ} \mathrm{C}$ in many other insects (Li et al., 2009; Rouland et al., 1988; Sami et al., 2011). Similarly, optimal temperature for xylanase activity was found to be $55^{\circ} \mathrm{C}$ in other insects (Fagbohoun et al., 2012; Liu et al., 2011; Roy et al., 2003). 
The effect of $\mathrm{pH}$ on the activities of endo- $\beta$-1,4-D-glucanase and endo- $\beta-1,4$-D-xylanase $O$. velox was examined at various $\mathrm{pH}$ values ranging from 4 to 10 . The optimal $\mathrm{pH}$ for the activities both endoglucanase and endoxylanase was found to be 5 (Fig. 4); at this $\mathrm{pH}$, their activities were $0.774 \pm 0.004 \mathrm{U} / \mathrm{mg}$ and $0.316 \pm 0.003 \mathrm{U} / \mathrm{mg}$ of protein, respectively. Although the optimal $\mathrm{pH}$ values for cellulase activity varies from acidic to alkaline (Hurst et al., 1997; Ito et al., 1989; Park et al., 2002), all animal cellulases reported till now have shown maximum activity only under week acidic conditions. Endoxylanase, which is the main xylanolytic enzymes characterized among insects, was found to show maximum activity in the $\mathrm{pH}$ range from 4.5 to 7 (Kouadio et al., 2016).

\section{Conclusions}

This study demonstrated the presence of both cellulolytic and xylanolytic activities in the gut fluid of $O$. velox. An analysis of the zymogram of gut fluid further revealed the proteins associated with these enzyme activities. Thus, $O$. velox could be considered as an attractive model for studying lignocellulose degradation in the insect guts. Further characterization of the efficient lignocellulolytic system of this insect may aid in the identification of novel enzymes with desirable characteristics for application in the biofuel industry. Moreover, insecticides can be developed targeting these novel enzymes to control this rice pest.

\section{References}

Ali S.S., Wu J., Xie R., Zhou F., Sun J., Huang M. (2017) Screening and characterizing of xylanolytic and xylose-fermenting yeasts isolated from the wood-feeding termite Reticulitermes chinensis. PLoS One 12(7): e0181141.

Arakawa G., Watanabe H., Yamasaki H., Maekawa H., Tokuda G. (2009) Purification and molecular cloning of xylanases form the wood feeding termite, Coptotermes formosanus shiraka. Biosci. Biotechnol. Biochem. 73(3): 710-718.

Brennan Y., Callen W.N., Christoffersen L., Dupree P., Goubet F., Healey S., Hernandez M., Keller M., Li K., Palackal N. et al. (2004) Unusual microbial xylanases from insect guts. Appl. Environ. Microbiol. 70(6): 3609-3617.

Cairo J.P.L.F., Leonardo F.C., Alvarez T.M., Rebeiro D.A., Buchli F, Costa-Leonardo A.M., Carazzolle M.F., Costa F.F., Leme A.F.P., Pereila G.A., et al. (2011) Functional characterization and target discovery of glycoside hydrolases from the digestome of the lower termite Coptotermes gestroi. Biotechnol. Biofuels 4: 50 .
Chen H. (2014) Chemical composition and structure of natural lignocellulose. [in:] Biotechnology of lignocellulose: theory and practice. Chemical Industry Press. Beijing: 25-71.

Clarke A.J. (1997) Biodegradation of cellulose: enzymology and biotechnology. Lancaster, PA: Technomic Pub. Co: 23-68.

Dodd D., Cann I.K.O. (2009) Enzymatic deconstruction of xylan for Biofuel Production. GCB Bioenergy 1: 2-17.

Eziashi E.I., Chidi N.I. (2017) Pathogenecity of entomopathogenic Entomopthora grylli on grasshoppers Diabolocatantops axillaris and Zonocerus variegatus causing leaf damage of shea tree seedlings. J. Agric. Crops Res. 5(1): 11-16.

Fagbohoun J.B., Karamoko Y., Dabonné S., Kauadio E.J.P., Dué E.A., Kauamé L.P. (2012) Characterization of the dual activity of an endo-beta-D-glycosidase from salivary glands of Macrotermes subhyalinus little soldier again carboxymethylcellulose and xylan. Int. J. Biomol. Biomed. 2: 8-14.

Fischer R., Ostate R., Tyman R.M. (2013) Cellulases from insects. Adv. Biochem. Eng. Biotechnol. 136: 51-64.

Geib S.M., Tien M., Hoover K. (2010) Identification of proteins involved in lignocellulose degradation using in gel zymogram analysis combined with mass spectroscopybased peptide analysis of gut proteins from larval Asian longhorned beetles, Anoplophora glabripennis. Insect Sci. 17: 253-264.

Girard C., Jouanin L. (1999) Molecular cloning of cDNAs encoding a range of digestive enzymes from a phytophagus beetle, Phaedon cochleariae. Insect Biochem. Mol. Biol. 29: 1129-1142.

IEO report (2016) Access: https://www.eia.gov/outlooks/ieo/ pdf/world.pdf

Juturu V., Wu J.C. (2012) Microbial xylanases: Engineering, production and industrial applications. Biotechnol. Adv. 30: 1219-1227.

Khandeparker R., Parab P., Amberkar U. (2017) Recombinant Xylanase from Bacillus tequilensis BT21: Biochemical characterization and its application production of xylobiose from agricultural residues. Food Technol. Biotechnol. 55(2): 164-172.

Kuhad R.C., Gupta R., Singh A. (2011) Microbial cellulases and their industrial applications. Enzyme Res. 2011: 280696.

Kumar S., Sulatana R., Wagan M.S., Panhwar W.A., Solangi H.S. (2014) Reduction in faeces production and food consumption by three rice grasshoppers after infection with Aspergillus species from Budin, Sindh. Int. J. Biosci. 4(4): 10-17.

Laemmli U.K. (1970) Cleavage of structural proteins during the assembly of the head of bacteriophage $T_{4}$. Nature 227: 680-685.

Li Y., Yin Q., Ding M., Zhao F. (2009) Purification, characterization and molecular cloning of a novel endo- $\beta-1,4-g l u c a n a s e$ AC-EG65 form the mollusc Ampullariacrossean. Comp. Biochem. Physiol. B Biochem. Mol. Biol. 91: 149-156.

Liu N., Yan X., Zhang M., Xie L., Wang Q., Huang Y., Zhou X., Wang S., Zhou Z. (2011) Microbiome of fungus-growing termites: a new reservoir for lignocellulase genes. Appl. Environ. Microbiol. 77: 48-56. 
Lowry O.H., Farr R.A.L., Randell R.J. (1951) Protein measurement with the Folin phenol reagent. J. Boil. Chem. 193: 265-275.

Lynd L.R., Laser M.S., Bransby D., Dale B.E., Davison B., Hamilton R., Himmel M., Keller M., McMillan J.D., Sheehan J., et al. (2008) How biotech can transform biofuels. Nat. Biotechnol. 26(2): 169-172.

Mattam A.J., Kuila A., Suralikerimath N., Choudary N., Rao P.V.C., Velankar H.R. (2016) Cellulolytic enzyme expression and simultaneous conversion of lignocellulosic sugars into ethanol and xylitol by a new Candida tropicalis strain. Biotechnol. Biofuels 9: 157.

Miller G.L. (1959) Use of dinitrosalicylic acid reagent for determination of reducing sugar. Anal Chem. 31: 426-428.

Mohamed M.A., Ghanem M.M.E., Abd-Elaziz, A.M., ShamsEldin, I.M. (2018) Purification and characterization of xylanase isozymes from Red palm weevil Rhynchophorus ferrugineus. Biocatal. Agric. Biotechnol. 14: 321-327.

Oppert C., Klingeman W.E., Willis J.D., Oppert B., Jurat-Fuentes J.L. (2010) Prospecting for cellulolytic activity in insect digestive fluids., Comparat. Biochem. Physiol. B: Biochem. Mol. Biol. 155: 145-154.

Padilla-Hurtado B., Florez-Ramos C., Aguirela-Galvez C., Medina-Olaya J., Ramirez-Sanjuan A., Rubio-Gomez J., AcunaJornosa R. (2012) Cloning and expression of an endo-1,4- $\beta$ xylanase from the coffee berry borer Hypothenemas hampei. BMC Res. Notes 5(1): 23-10.1186/1756-0500-5-23.

Rouland C., Civas A., Renox J., Petek F. (1988) Purification and properties of cellulases from the termite Macrotermes mulleri (Termitidae, Macrotermitinae) and its symbiotic fungus Termitomyces sp. Comp. Biochem. Physiol. 91B(3): 449-458.

Roy N., Rana M.M., Uddin, A.T.M.S. (2004) Isolation and some properties from new xylanase from the intestine of a herbivorous insect (Samia Cynthia pryeri). J. Biol. Sci. 4: 27-33.

Rubin E.M. (2008) Genomics of cellulosic biofuels. Nature 454: 841-845.

Sami A.J., Anwar M.A., Rehman F.U., Shakoori A.R. (2011) Digestive cellulose hydrolyzing enzyme activity (endo- $\beta-1,4$ glucanase) in the gut and salivary glands of blister beetle, Mylabris pustulata. Pakistan J. Zool., 43(2): 393-401.

Sami A.J., Shakkori A.R. (2006) Heterogeneity of cellulases of some of the local agricultural insect pests. Pakistan J. Zool. 38(4): 337-340.

Schubert C. (2006) Can biofuels finally take center stage?Nat. Biotechnol. 24(7): 777-784.

Schwarz W.H., Grabnitz B.F., Staudenbauer W.L. (1987) Activity staining of cellulases in polyacrylamide gels containing mixed linkage $\beta$-glucans. Anal. Biochem. 164: 72-77.

Shelomi M., Heckel D.G., Pauchet Y. (2016) Ancestral gene duplication enabled the evolution of multifunctional cellulases in stick insects (Phasmatodea). Insect Biochem. Mol. Biol. 71: 1-11.

Sheng P., Li Y., Marshall S.D.G., Zhang H. (2015) High genetic diversity of microbial cellulase and hemicellulase genes in the hindgut of Holotrichia parallela larvae. Int. J. Mol. Sci. 16: 16545-16559.

Shi W., Ding S.Y., Yuan J.S. (2011) Comparison of insect gut cellulase and xylanase activity across different insect species with distinct food sources. Bioenerg. Res. 4: 1-10.

Shil R.K., Mojumder S., Sadida F.F., Uddin, M., Sikdar D. (2014) Isolation and identification of cellulolytic bacteria form from three phytophagous insect species. Braz. Arch. Biol. Technol. 57(6): 927-932.

Su L.J., Zhang H.F., Yin X.M., Chen M., Wang F.Q., Xie H., Zhang G.Z., Song A.D. (2013) Evaluation of cellulolytic activity in insect digestive fluids. Genet. Mol. Res. 12(3): 2432-2441.

Sun J.Z., Scharf M.E. (2010) Exploring and integrating cellulolytic systems of insects to advance biofuel technology. Insect Sci. 17: 163-165.

Teather R.M., Wood P.J. (1982) Use of congo red polysaccharide interactions in enumeration and characterization of cellulolytic bacteria from the bovine rumen. Appl. Environ. Microbiol. 43: 777-780.

Terrapon N., Li C., Robertson H.M., Ji L., Meng X., Booth W., Chen Z., Childers C.P., Glastad K.M., Gokale K. et al. (2014) Molecular traces of alternative social organization in a termite genome. Nat. Commun. 5: 3636. DOI: 10.1038/ ncomms4636.

Uday U.S.P., Bandyopadhyay T.K., Goswami S., Bhunia, B. (2017) Optimization of physical and morphological regime for improved cellulose free xylanase production by fed batch fermentation using Aspergillus niger (874102.1) and its application in bio-bleaching. Bioengineered 8(2): 137-146.

Uddin M.M., Chowdhury M.M.H. Mojumder S., Sikdar, D. (2012) Multiple endo- $\beta$-1,4-glucanases present in the gut fluid of a defoliating beetle, Podentia Quatuordecimpunctata (Coleoptera: Crysomelidae). Pak. J. Biol Sci. 15(7): 333-340.

Waeonukul R., Kyo K.L., Ratanakhanokchai K. (2007) Multiple cellulases and xylanases from Bacillus circulans $B_{6}$ during growth on avicel under aerobic condition. Thai J. Biotechnol. 8: 27-32.

Wakiyama M., Tanaka H., Yoshihara K., Hayashi S., Ohta K. (2008) Purification and properties of family-10 endo-1,4[beta]-xylanase from Penicllium citrinum and structural organization of encoding gene. J. Biosci. Bioeng. 105(4): 367-374.

Watanabe H., Takuda, G. (2010) Cellulolytic systems in insects. Ann. Rev. Entomol. 55: 609-632.

Wei Y.D., Lee S.J., Lee K.S., Guiand J.J., Yoon H.J., Kim I., Je Y.H., Guo X., Sohn H.D., Jin B.R. (2005) N-glycosylation is necessary for enzymatic activity of beetle, (Apriona germari) cellulase. Biochem. Biophys. Res. Commun. 329: 331-336.

Wills J.D., Oppert B., Oppert C., Klingeman W.E., Jurat-Fuentes J.L. (2011) Identification, cloning, and expression of a GHF9 cellulase from Tribolium castaneum (Coleoptera: Tenebrionidae). J. Insect Physiol., 57: 300-306

Wills J.D., Klingeman W.E., Oppert C., Jurat-Fuentes J.L. (2010a) Characterization of cellulolytic activity from diges- 
tive fluids of Dissosteira carolina (Orthoptera: Acrididae). Comp. Biochem. Physiol. B: Biochem. Mol. Biol. 157(3): 267-272.

Wills J.D., Oppert C., Jurat-Fuentes J.L. (2010b) Methods for discovery and characterization of cellulolytic enzymes from insects. Insect Sci. 17: 184-198.

Xu B., Dai L., Li J., Deng M., Miao H., Zhou J., Mu Y., Wu Q., Tang X., Yang Y. et al. (2016) Molecular and Biochemical characterization of a novel xylanase from Massilia $s p$. RBM26 isolated from the feces of Rhinopithecus bieti. J. Microbiol. Biotechnol. 26(1): 9-19.
Yang B., Dal Z., Ding S.Y., Wyman C.E. (2011) Enzymatic hydrolysis of cellulosic biomass. Biofuels 2(4): 421-450.

Yang H., Yan R., Chen H., Lee D.H., Zheng C. (2007) Characteristics of hemicellulose, cellulose and lignin pyrolysis. Fuel 86: 1781-1788.

Zhang J.,Siika-aho M., Puranen T., Tang M., Tenknen M., Viikari L. (2011) Thermostable recombinant xylanases from Nonomuraea flexuosa and Thermoascus aurantiacus show distinct properties in the hydrolysis of xylans and pretreated wheat straw. Biotechnol. Biofuels 4: 12 . 